\title{
Analysis of public transport demand in the Municipality of Stupnik
}

DOI: https://doi.org/10.7307/ptsm.2020.2

\author{
Ljupko Šimunović ${ }^{1}$, Marko Slavulj ${ }^{1}$, Mario Ćosić ${ }^{1}$, Matija Sikirić ${ }^{1}$
}

Faculty of Transport and Traffic Sciences, University of Zagreb ${ }^{I}$

\author{
Keywords: \\ Public transport \\ Transport demand \\ Bus transport \\ Stupnik
}

\begin{abstract}
Public transport is the backbone of urban mobility, providing people with access to employment, education, trade and daily activities. It provides a special benefit to people who do not own a car and are dependent on well-organized public transport. The paper presents an analysis of the demand for public transport services in the Municipality of Stupnik, otherwise organized in the form of bus transport. The paper presents the methodology used, as well as the obtained results, and the associated discussion and conclusion.
\end{abstract}

\section{Introduction}

Public transport, (also called mass transport) is the movement of people within urban areas using group travel technologies such as bus, train, metro and tram. [1] Public transport of passengers in the municipality of Stupnik is organized as bus transport. [2] Buses use conventional roads to transport numerous passengers on shorter travel routes. They operate at low capacity compared to trams or trains and can operate on conventional roads, with relatively inexpensive bus stops serving to collect passengers. Therefore, buses are commonly used in smaller cities and rural areas, as well as for transportation services that complement other types of transit in large cities. [1]

Most of the inhabitants of the Municipality using public transport fulfil their needs for transport by bus, and only a small part uses the railway (HŽ Passenger transport), i.e. the railway station in Hrvatski Leskovac. The paper is based on a study prepared by the Faculty of Transport and Traffic Sciences, entitled "Analysis of public transport in the territory of the Municipality of Stupnik". The second chapter describes the scope and organization of public transport. The third chapter describes the research methodology used, referring to the counting of passengers in public transport vehicles and conducting a survey. The fourth chapter presents the results of the research, followed by discussion and conclusions.

\section{Catchment area}

The area of the Municipality of Stupnik has been determined for conducting the research. The municipality of Stupnik is located in the western part of Zagreb County. It borders the City of Zagreb to the north, east and south, to the northwest to the Municipality of Sveta Nedelja, and to the west with the City of Samobor. The total area of the municipality of Stupnik is $24.87 \mathrm{~km} 2$. According to the 2011 census, the municipality has 3,735 inhabitants. Territorially, the Municipality of Stupnik includes three settlements: Gornji Stupnik, Donji Stupnik and Stupnički Obrež. The population density is 149.3 inhabitants $/ \mathrm{km} 2$, from which it can be concluded that the Municipality of Stupnik is quite sparsely populated in terms of its characteristics and belongs to the suburbs of the City of Zagreb, Zagreb County. [3]

Public transport in the area of the Municipality of Stupnik is performed by the Zagreb Electric Tram operator from Zagreb d.o.o. (hereinafter ZET). The analysed area is shown in Figure 1. 


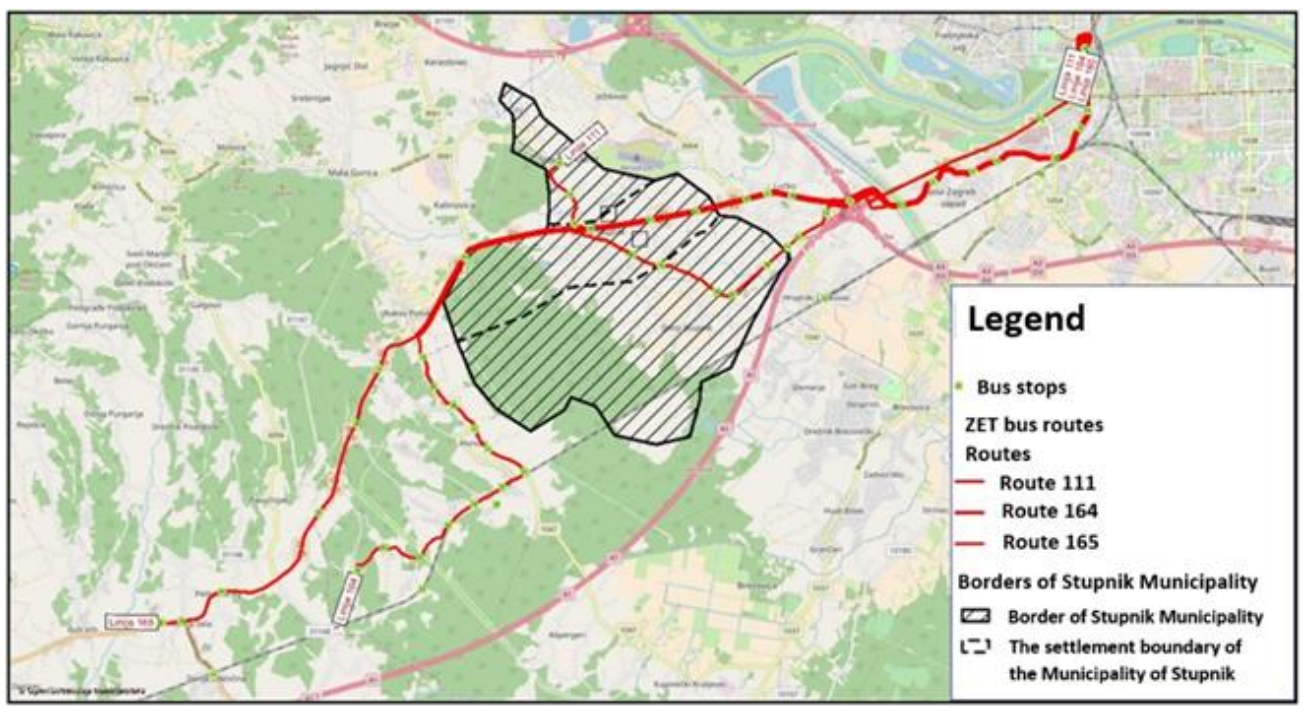

Figure 1. Spans of bus lines in the municipality of Stupnik

Source: [2]

There are three bus routes operated by ZET [4]:

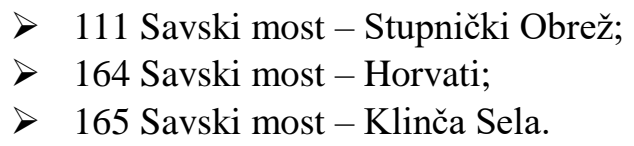

All three bus routes serve as transport collectors and provide passengers with traffic connections to the Savski most terminal in Zagreb, where passengers can continue to use other ZET's tram and bus routes.

\section{Methodology}

In order to get an overview of transport demand in the Stupnik area, research was conducted in the form of counting passengers on bus lines and conducting a survey of the population.

\section{Passenger counting}

The counting of passengers on bus lines was carried out with the aim of obtaining the actual load on the lines and the number of passengers using public transport by bus in the observed area. Also, passenger counting data are used to compare the transport demand model in public transport (data obtained from a survey of transport system users) with the actual state of passenger flows on the lines. [5] [6]

In order to obtain a better sample and the possibility of correcting errors in the process, the counting of passengers was carried out over two working days - Thursday, March 22, 2018 and Tuesday, March 26, 2018 on three bus lines [2]:

$>111$ Savski most - Stupnički Obrež;

$>164$ Savski most - Horvati;

$>165$ Savski most - Klinča Sela.

The exact number of "entered" and "exited" passengers, and the exact number of passengers between stops could be determined with high accuracy by one passenger counter in one vehicle (because vehicle occupancy never exceeded 50\% of standing places, and meters did not have to manually record driving times). [5] [6] 


\section{Survey research}

Survey - The analysis of public transport in the Municipality of Stupnik was conducted methodologically in two ways. The first way was a web survey, and the second was the physical completion of a survey form that elementary school students in Stupnik took home and filled out with other household members. The survey was conducted on a sample of 242 respondents. With an accuracy of $95 \%$, the error is $6.1 \%$. Implementation time is the second half of March 2018. [2]
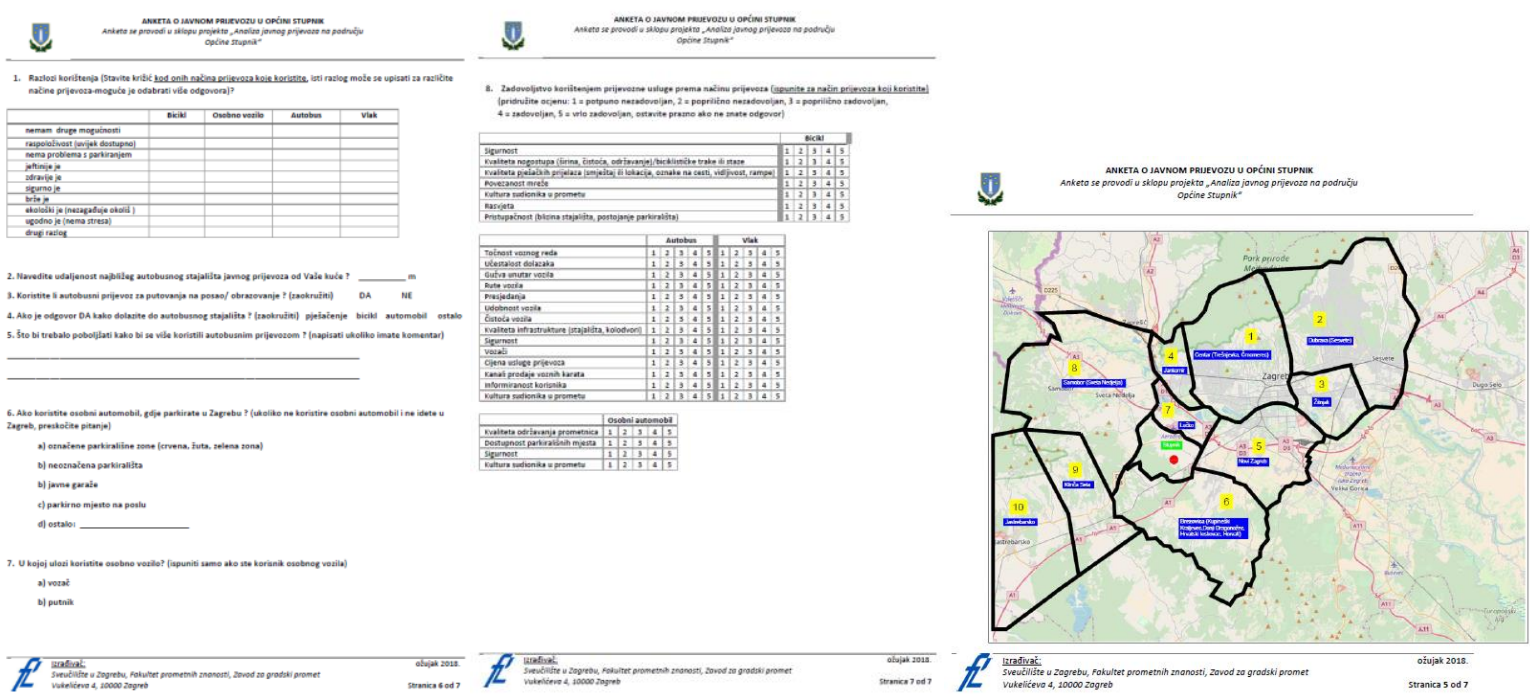

Figure 2. Example of a survey questionnaire

Source: [2]

The aim of the survey is to gather information about [2]:

$>$ age and gender structure of residents;

$>$ employment status of residents;

$>$ possession of a driver's license;

$>$ number of personal vehicles and bicycles in the household;

$>$ share of bus transport and car users;

$>$ distance of bus stops from the place of residence;

$>$ form of car parking;

$>$ determine the reasons for using a personal car, public transport and bicycle;

$>$ establish the desire lines of the residents;

$>$ purpose of travel;

$>$ main mode of travel;

$>$ reasons for dissatisfaction with the public transport service.

\section{Results}

The results of passenger counting and survey research in the area of the Municipality of Stupnik are presented below.

\section{Passenger counting}

Counting passengers on bus lines showed that the occupancy of buses on any line never exceeds $27 \%$, so due to the large share of seats of $35 \%$, typical for suburban buses, most buses do not fill seats on average. [2] 
The following results were determined by counting the passengers who entered and left the area of the Municipality of Stupnik in three counting periods (morning, early afternoon and late afternoon) [2]:

$>\quad$ in the morning counting period, most passengers leave at the Mercatone stop (18 passengers), while most of them enter at the stops Gornjostupnička (14 passengers) and Stupnik - Osnovna škola (11 passengers).;

$>$ at other stops, the number of passengers entered is higher than the number of passengers;

$>$ in the early afternoon counting, most passengers enter at the stop Osnovna škola (11 passengers), while most passengers leave at the stops Gornjostupnička (13 passengers), Domovićeva (5 passengers) and Stupnički obrež (5 passengers);

$>$ at other stops the number of passengers entered and exited is the same;

$>$ in the late afternoon, most passengers leave at Gornjostupnička (17 passengers), Domovićeva (9 passengers) and Donjnostupnička (9 passengers), while most passengers enter at Gornjostupnička (7 passengers);

$>$ at other stops, the number of exited passengers is many times higher.

Number of passengers per vehicle, and the number of passengers who boarded and disembarked at stops for one typical ride on each line in periods [2]:

06:45-08:15 (morning, which represents morning trips to work and school);

$>$ 13:00-14:30 (early afternoon, which represents trips from the place of school to the place of residence);

$>$ 15:00-16:30 (late afternoon, which represents trips from work to the place of residence).

According to the collected data, the number of passengers using the bus from the area of the Municipality of Stupnik and their share in the total number of passengers is shown in Table 1. According to Table 1, line 111 (ending in the Municipality of Stupnik) carries $70 \%$ of the passengers of the Municipality of Stupnik, and the remaining two lines passing through the Municipality of Stupnik carry 23\% (164) and 28\% (165). [2]

Table 1. Number and share of passengers from the Municipality of Stupnik by lines and directions

\begin{tabular}{|c|c|c|c|c|}
\hline \multicolumn{2}{|r|}{ Line } & $06: 45-08: 15$ & $13: 00-14: 30$ & $15: 00-16: 30$ \\
\hline 111 & Savski most - Stupnički Obrež & $26(65 \%)$ & $17(55 \%)$ & $29(67 \%)$ \\
\hline 111 & Stupnički Obrež - Savski most & $47(59 \%)$ & $34(92 \%)$ & $12(80 \%)$ \\
\hline 164 & Savski most - Horvati & $4(18 \%)$ & $3(5 \%)$ & $8(33 \%)$ \\
\hline 164 & Horvati - Savski most & $11(69 \%)$ & $2(8 \%)$ & $3(15 \%)$ \\
\hline 165 & Savski most - Klinča sela & $5(26 \%)$ & $8(26 \%)$ & $15(37 \%)$ \\
\hline 165 & Klinča sela - Savski most & $7(64 \%)$ & $1(2 \%)$ & $2(12 \%)$ \\
\hline
\end{tabular}

Source: [2]

Based on the traffic counting data, an analysis of the occupancy of public transport vehicles was made. Vehicle occupancy in most cases is less than the number of filled seats. The obtained average occupancy of the vehicle in relation to the capacity is [2]:

$>$ on the line 111: 24\%;

$>$ on the line 164: $15 \%$;

$>$ on the line 165: $17 \%$.

Vehicle occupancy is classified into three categories and shown in Table 2 [2]:

$>$ seats filled $0 \%-100 \%$, standing capacity unfilled;

$>$ filled seats, standing capacity filled $0 \%-25 \%$;

$>$ filled seats, standing capacity filled $25 \%-50 \%$. 
Table 2. Vehicle occupancy on bus lines

\begin{tabular}{|c|c|c|c|c|c|c|c|c|c|c|c|c|}
\hline \multirow[t]{2}{*}{ Line } & \multicolumn{4}{|c|}{$06: 45-08: 15$} & \multicolumn{4}{|c|}{$13: 00-14: 30$} & \multicolumn{4}{|c|}{$15: 00-16: 30$} \\
\hline & $\frac{80}{8}$ & $\begin{array}{l}\stackrel{0}{2} \\
\stackrel{2}{2} \\
\vdots \\
\vdots\end{array}$ & 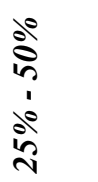 & 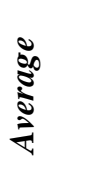 & $\frac{\stackrel{0}{8}}{\stackrel{8}{8}}$ & $\begin{array}{l}\stackrel{8}{2} \\
\stackrel{2}{2} \\
\vdots \\
\vdots\end{array}$ & 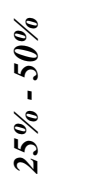 & 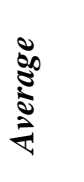 & $\frac{\stackrel{8}{8}}{\frac{1}{8}}$ & $\begin{array}{l}\frac{8}{2} \\
\stackrel{2}{0} \\
\vdots \\
\vdots\end{array}$ & 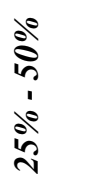 & 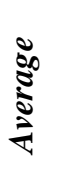 \\
\hline 111 & $69 \%$ & $26 \%$ & $5 \%$ & $23 \%$ & $66 \%$ & $34 \%$ & $0 \%$ & $27 \%$ & $73 \%$ & $27 \%$ & $0 \%$ & $22 \%$ \\
\hline 164 & $82 \%$ & $12 \%$ & $6 \%$ & $19 \%$ & $100 \%$ & $0 \%$ & $0 \%$ & $13 \%$ & $100 \%$ & $0 \%$ & $0 \%$ & $14 \%$ \\
\hline 165 & $100 \%$ & $0 \%$ & $0 \%$ & $16 \%$ & $100 \%$ & $0 \%$ & $0 \%$ & $15 \%$ & $78 \%$ & $22 \%$ & $0 \%$ & $21 \%$ \\
\hline
\end{tabular}

Source: [2]

It is observed that cases prevail in which the occupancy of vehicles does not exceed the number of filled seats along the lines in any observed period. Furthermore, data on vehicle occupancy show insufficient utilization of the offered transport work on the lines (it is better used on line 111). [2]

\section{Survey research}

The survey was conducted on a sample of 242 respondents. With an accuracy of $95 \%$, the error is $6.1 \%$. Implementation time is the second half of March 2018. In total, 38\% of men and 62\% of women completed the survey. The largest share (38\%) belongs to the age group of 40 to 65 years, followed by the age group of 25 to 39 years to which $34 \%$ of respondents belong. The least number of respondents belongs to the age groups of respondents older than 65 years (8\%) and age groups of respondents aged 15 to 19 years (7\%), and persons younger than 14 years $(2 \%)$. The average age of the surveyed respondents is 39.5 years. [2]

The survey covered $65 \%$ of employed persons, $8 \%$ of schoolchildren, $17 \%$ of pensioners and $5 \%$ of students. The average number of household members of the surveyed participants was 4.8 members. According to the possession of a driver's license, $76 \%$ of respondents answered in the affirmative, and $24 \%$ of respondents answered in the negative. [2]

According to the number of passenger cars they own, $37 \%$ of respondents own one car, $36 \%$ of respondents own two cars, three cars $17 \%$ of respondents and four or more cars own $7 \%$ of respondents while $4 \%$ of respondents do not own a car. The average number of cars per household of the surveyed respondents is 1.91. [2]

According to the number of personal bicycles they own, $25 \%$ of respondents own two bicycles, while $21 \%$ of respondents own one bicycle, three bicycles $20 \%$ of respondents and four $13 \%$ of respondents. 5 and more bicycles are owned by $12 \%$ of respondents while $7 \%$ of respondents do not own a bicycle. The average number of bicycles per household of the surveyed respondents is 2.58. [2]

Bus transport is used by $59 \%$ of respondents while $41 \%$ of respondents stated that they do not use bus transport. [2]

The distance that respondents travel to the bus stop is between $400-800 \mathrm{~m}$ for $32 \%$ of respondents, $800-1200$ $\mathrm{m}$ for $29 \%$ of respondents. A distance of up to $400 \mathrm{~m}$ to the stop is covered by $28 \%$ of respondents and a distance greater than $1200 \mathrm{~m}$ is covered by $11 \%$ of respondents. Most of the respondents reach the bus stop on foot. The average distance considering all the answers of the respondents is $675 \mathrm{~m}$. [2]

Regarding the use of a car, $66 \%$ of respondents use a car as a driver, and $34 \%$ of respondents use a car as a passenger. When it comes to parking a car, the largest number of respondents (29\%) park their car in the marked 
parking zone, while $26 \%$ of respondents park their car in the parking lot at work. $15 \%$ of respondents park in an unmarked parking lot, while $14 \%$ of respondents use public garages. [2]

Respondents were asked about the reasons for using a bicycle. A large proportion of respondents (24\% of the survey sample) point out that the main reason for using a bicycle is that it is healthier. Other reasons for using a bicycle are that the bicycle is cheaper (17\%), environmentally friendly (16\%), comfortable and has no problems with parking (11\%), while the bicycle is considered a fast form of transport (2\%). [2]

The most common reason for using a personal car, among the surveyed users is speed (37\%), followed by accessibility (27\%) and comfort (14\%). Of all surveyed users, $11 \%$ use a personal car because there are no problems with parking. Safety, as a reason for using a car points out (4\%) respondents. [2]

Also, respondents were asked about the reasons for using the bus. A large part of the respondents (23\% of the survey sample) point out that the main reason for using buses is that they do not have problems with parking and because such a mode of transport is cheaper (22\%). Other reasons for using the bus are that the bus is accessible and safe (10\%), comfortable (9\%) and fast (7\%). [2]

Table 3. Travels from the Municipality of Stupnik to other zones

\begin{tabular}{|l|c|}
\hline Destination & Proportion of passengers from the Municipality of Stupnik in percent \\
\hline Centre & $41.1 \%$ \\
\hline Dubrava & $4.5 \%$ \\
\hline Žitnjak & $4.9 \%$ \\
\hline Jankomir & $4.5 \%$ \\
\hline Novi Zagreb & $18.1 \%$ \\
\hline Brezovica & $0.8 \%$ \\
\hline Lučko & $10.2 \%$ \\
\hline Samobor & $3.0 \%$ \\
\hline Klinča Sela & $0.4 \%$ \\
\hline Jastrebarsko & $0.8 \%$ \\
\hline Other & $11.7 \%$ \\
\hline
\end{tabular}

Source: [2]

Due to the gravity of the Municipality of Stupnik towards the City of Zagreb, trips from the Municipality of Stupnik to the area of the City of Zagreb are highly represented in the morning peak period. [2]

From the table and figure it can also be seen that, considering the selected zones in the City of Zagreb, the largest share of trips to the zone of the centre of Zagreb (Centre), Novi Zagreb and Lučko, i.e. all trips are in the northeast direction (in the direction of the City of Zagreb), which is in line with the larger offer of facilities that attract a large number of passengers in the centre of Zagreb. [2]

Due to the gravity of the Municipality of Stupnik towards the City of Zagreb, travel from the area of the City of Zagreb to the Municipality of Stupnik is highly represented in the afternoon peak period. [2] 


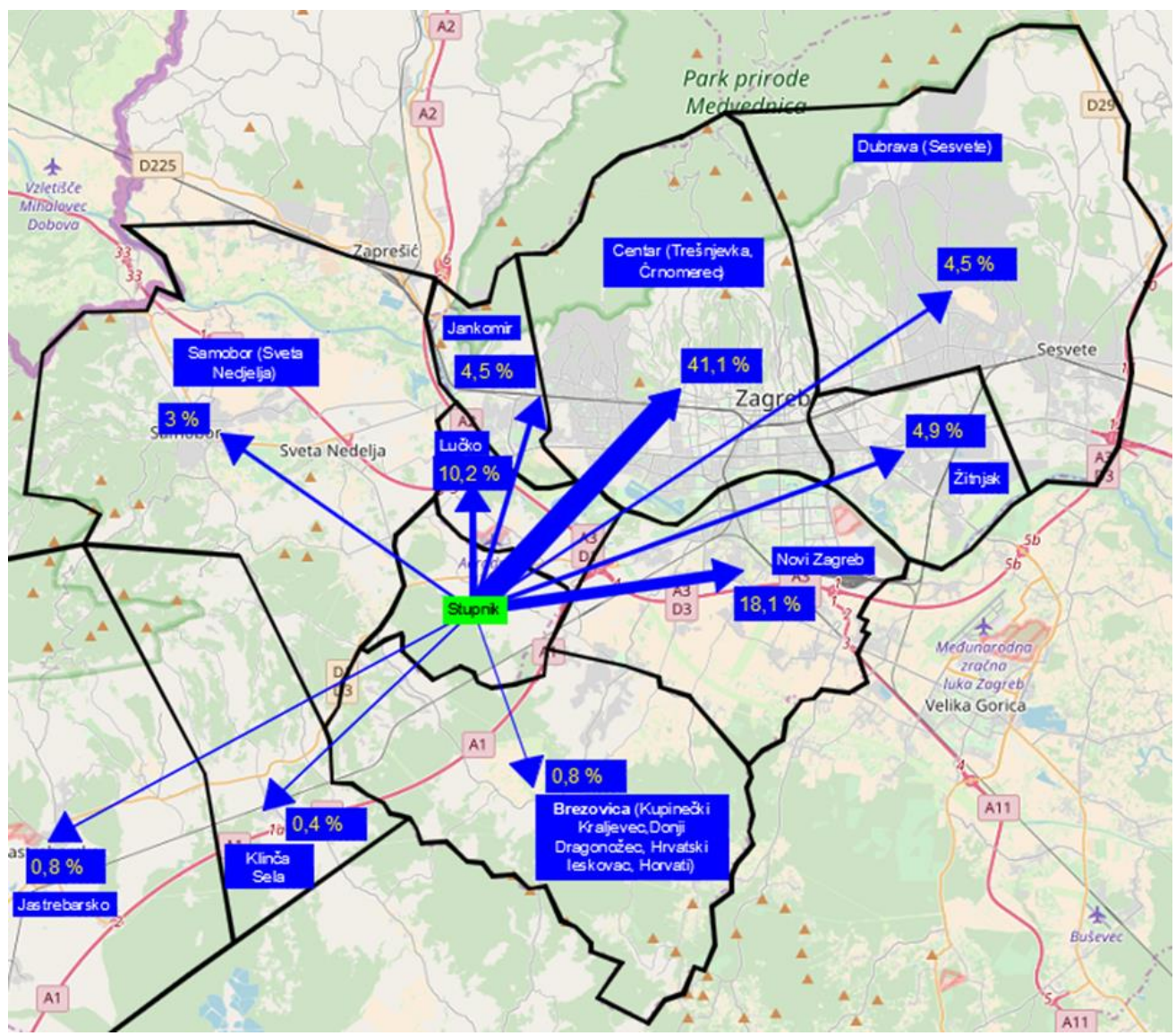

Figure 3. Graphic representation of desire lines from the Municipality of Stupnik Source: [2]

Table 3. Travels from other zones to the Municipality of Stupnik

\begin{tabular}{|l|c|}
\hline Destination & Proportion of passengers to the Municipality of Stupnik in percent \\
\hline Centre & $41.0 \%$ \\
\hline Dubrava & $2.8 \%$ \\
\hline Žitnjak & $6.3 \%$ \\
\hline Jankomir & $6.3 \%$ \\
\hline Novi Zagreb & $18.1 \%$ \\
\hline Brezovica & $0.7 \%$ \\
\hline Lučko & $10.4 \%$ \\
\hline Samobor & $2.8 \%$ \\
\hline Klinča Sela & $0.0 \%$ \\
\hline Jastrebarsko & $0.0 \%$ \\
\hline Other & $11.8 \%$ \\
\hline
\end{tabular}

Source: [2]

If the data are compared with those in the morning peak period, the table and figure show that afternoon trips are practically a copy of morning trips in terms of travel share, which indicates the constancy of travel desire lines and their usual character (trips are direct and take place on the route - housing or schooling - housing). Most trips come from the same observed zones as in the morning peak period - the center of Zagreb, Novi Zagreb and Lučko. The interaction of a significant share of passengers with the Lučko zone is a consequence of the position of the municipality between the Municipality of Stupnik and the City of Zagreb. [2] 


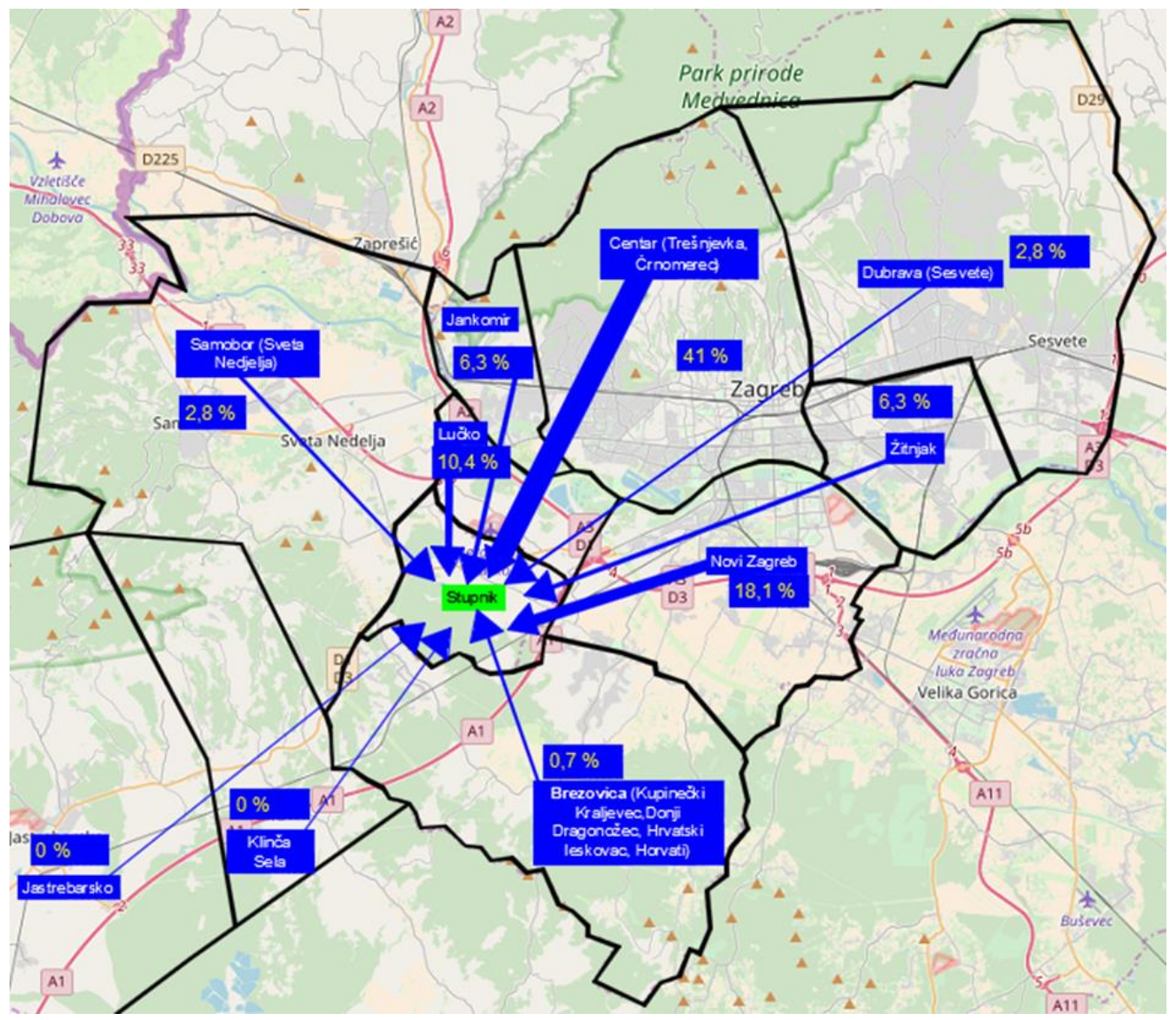

Figure 4. Graphic presentation of travel desire lines to the Municipality of Stupnik Source: [2]

When asked about the purpose of the trip, the majority of respondents stated that the purpose of their trip was most often to return home (29\%) and go to work (34\%). Furthermore, the most common purpose of travel for respondents is going shopping (13\%), going to school or college $(6 \%)$, recreation $(3 \%)$ and other reasons as the purpose of travel (14\%). [2]

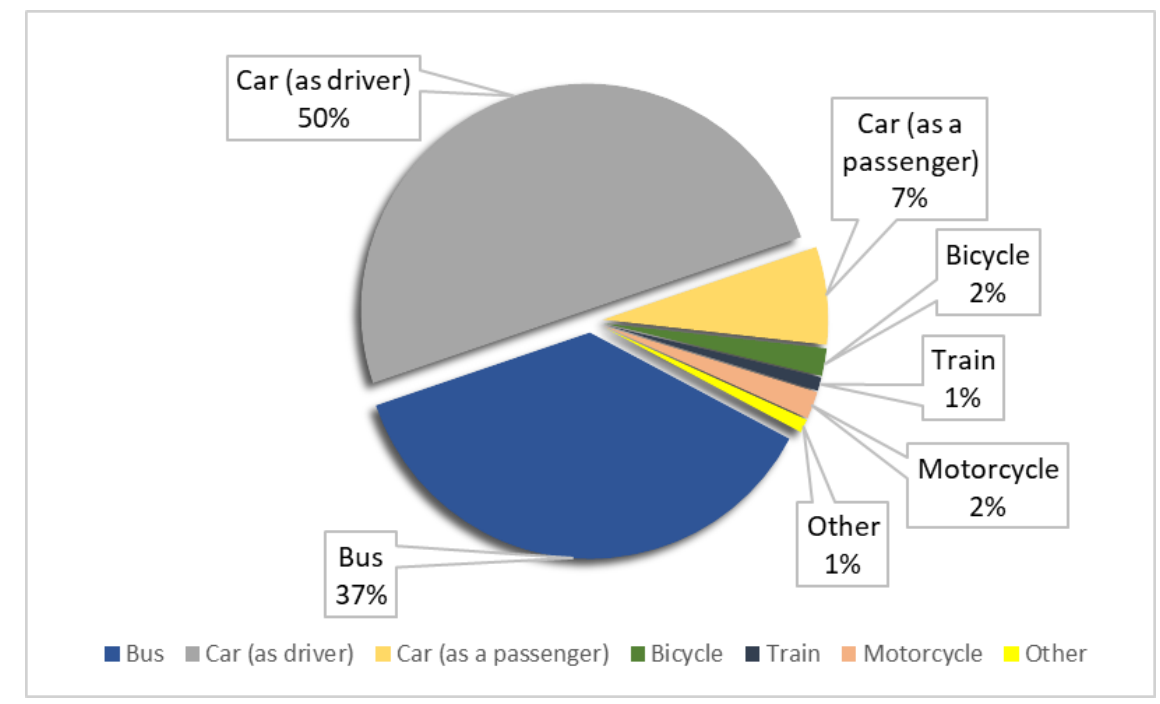

Figure 5. The main mode of travel obtained from the survey 
Source: [2]

As the main mode of travel for the surveyed users, the respondents most often state the use of cars as drivers (50\%), followed by the bus (37\%), the use of cars as passengers (7\%) and to a lesser extent bicycles $(2 \%)$, motorcycles (1\%) and train (1\%). [2]

In the survey, passengers were given the opportunity to comment on the existing bus system. Traveller comments were divided into nine general categories [2]:

$>$ inadequate information for passengers;

$>$ low operating speed, poor vehicle priority, buses stuck in traffic jams;

$>$ poor response of the vehicle in relation to the given timetable - poor accuracy of arrivals;

$>$ unsatisfactory timetable and regularity of vehicles;

$>$ poor tariff system, tariff zones, method of payment, high freight rates;

$>$ vehicle overcrowding, poor vehicle interior maintenance, poor vehicle interior design;

$>$ unsatisfactory line routes, stop positions, small number of lines;

$>$ unfriendly driving staff and aggressive driving;

$>$ poor infrastructure for passengers and vehicles.

According to the above categories, the obtained results are shown in Figure 6. It can be noticed that the biggest problem for passengers is poor timetable and regularity of vehicles $(62 \%)$, in which the higher number of departures in a short time and the lack of departures in the period that follows (departures are non-uniform). Also, passengers complained about the network itself - line routes, stop positions and number of lines (21\%). In addition, passengers also highlighted infrastructure as a problem (11\%), highlighting the lack of sidewalks in the Municipality of Stupnik, which causes reduced safety for pedestrians, especially for children and pensioners. [2]

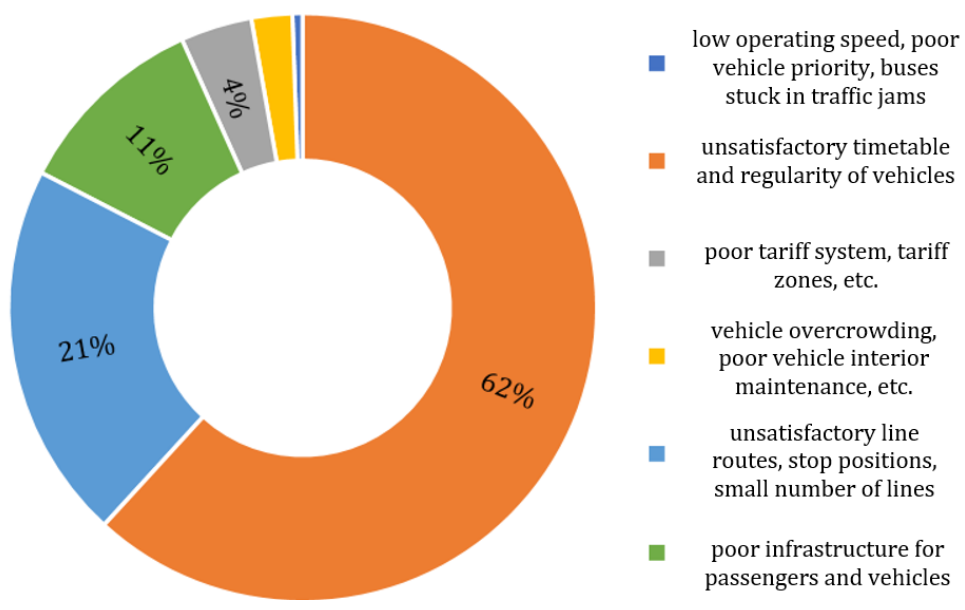

Figure 6. The categories that passengers complained about the most

Source: [2]

\section{Discussion}

The counting of passengers on bus lines in the Municipality of Stupnik was carried out with the aim of obtaining the actual load on the lines, and the number of passengers in the observed area who use public transport by bus.

In none of the observed vehicles did the occupancy exceed 27\%. There are cases where the occupancy of vehicles is below the level of filled seats, so that on line 111 the average occupancy is 24\%, and on lines 164 and 165 even lower - $15 \%$ on line 164 , and $17 \%$ on line 165 .

The most represented age group in the surveyed sample was between 40 - 65 years (38\%) and between 25 - 39 years $(34 \%)$, which represents the share of the working age population. Accordingly, employed persons, pupils 
and students comprise $74 \%$ of respondents. When it comes to owning a personal car, $37 \%$ of respondents own one car while $36 \%$ of respondents own two cars. The average number of cars per household of respondents is 1.91.

Only $7 \%$ of respondents do not own a bicycle, while $25 \%$ of respondents own two bicycles in the household. The average number of bicycles per household of the surveyed respondents is 2.58 .

Bus transport is used by $59 \%$ of respondents. The average distance to the bus stop is $675 \mathrm{~m}$. The main reasons for using the bus are the lack of parking problems and the favourable price. The most frequent parking space for personal cars of the surveyed respondents is in the marked parking zones $29 \%$, and in the parking space at work $26 \%$.

The main purpose of travel for about $2 / 3$ of respondents is to go to work and / or return home, and the main way to travel is a car $57 \%$ (driver and passenger), and a bus $37 \%$.

Considering the selected zones in the City of Zagreb, the largest share of travel is towards the zones of the centre of Zagreb, Novi Zagreb and Lučko, i.e. almost all travel routes are in the direction of the City of Zagreb. The share of travel to Samobor is a slight $3 \%$.

\section{Conclusion}

The analysis of the modal distribution of travel shows that the largest share of the population of the Municipality uses a car $(57 \%)$ for travel to work, school, and other needs towards the City of Zagreb. Public transport participates in the modal distribution in the amount of $37 \%$, while the bicycle with a share of $2 \%$ does not play a significant role in transport to the City of Zagreb. It is estimated that the share of car travel in the modal distribution is too high, if we look at trips to work, school and other activities.

Analysing the transport offer, it can be concluded that all three lines that serve the area of the Municipality (especially in peak periods of the day with the purpose of going to work and school), have sufficient capacity, bus units are filled on average $24 \%$, line 111 and $15-17 \%$, lines 164,165 ).

The railway, whose stop is in nearby Hrvatski Leskovac, is faster as a way of traveling, but has a smaller number of departures, which are even rarer in off-peak periods. The problem of accessibility of the railway is the main reason for its insignificant use by the inhabitants of the Municipality of Stupnik (only $2 \%$ of the population uses the railway as a way of traveling).

Since the Municipality of Stupnik is a settlement in the Zagreb County, its travel needs gravitate to the City of Zagreb and the settlements in the Municipality are suburban, it is possible to conclude that the existing public passenger transport is not sufficiently stimulating for a large number of passengers from the Municipality of Stupnik to use public passenger transport to perform their regular activities (traveling to work and school).

Since one of the goals is to increase the orientation, i.e. the share of travel by public, instead of personal transport, it is necessary to find solutions that would give the population easier access to public transport, primarily rail.

\section{References}

[1] Brčić, D., Slavulj, M. Urbana mobilnost. Fakultet prometnih znanosti. Zagreb. 2019.

[2] Fakultet prometnih znanosti. Analiza javnog prijevoza na području Općine Stupnik. Fakultet prometnih znanosti. Zagreb. 2018.

[3] Općina Stupnika. Ostali dokumenti. Available at: http://www.stupnik.hr/ostali-dokumenti/ [Accessed: April 15, 2018]

[4] Zagrebački električni tramvaj. Dnevne linije. Available at: https://www.zet.hr/autobusni-prijevoz/dnevnelinije-251/251 [Accessed: April 18, 2018] 
Šimunović, Lj., Slavulj, M., Ćosić, M., Sikirić, M. / Public Transport \& Smart Mobility 2020, 14-24

[5] Štefančić, G. Tehnologija gradskog prometa I. Fakultet prometnih znanosti. Zagreb. 2008.

[6] Štefančić, G. Tehnologija gradskog prometa II. Fakultet prometnih znanosti. Zagreb. 2010. 